\title{
Solvent-Free Ring Cleavage Hydrazinolysis of Certain Biginelli Pyrimidines
}

\author{
Mohamed A. Said, ${ }^{1}$ Wagdy M. Eldehna $\left(\mathrm{D},{ }^{2}\right.$ Hazem A. Ghabbour ${ }^{(D)},{ }^{3,4}$ \\ Maha M. Kabil, ${ }^{5}$ Nasser S. Al-shakliah, ${ }^{3,6}$ and Hatem A. Abdel-Aziz $\mathbb{i D}^{7}$ \\ ${ }^{1}$ Department of Pharmaceutical Chemistry, Faculty of Pharmacy, Egyptian Russian University, Badr City, Cairo, Egypt \\ ${ }^{2}$ Department of Pharmaceutical Chemistry, Faculty of Pharmacy, Kafrelsheikh University, Kafrelsheikh, Egypt \\ ${ }^{3}$ Department of Pharmaceutical Chemistry, College of Pharmacy, King Saud University, P.O. Box 2457, Riyadh 11451, Saudi Arabia \\ ${ }^{4}$ Department of Medicinal Chemistry, Faculty of Pharmacy, Mansoura University, Mansoura 35516, Egypt \\ ${ }^{5}$ Department of Infection Control, King Saud University Medical City, Riyadh, Saudi Arabia \\ ${ }^{6}$ Department of Pharmaceutical Chemistry, College of Pharmacy, Aden University, Aden, Yemen \\ ${ }^{7}$ Department of Applied Organic Chemistry, National Research Center, Dokki, Cairo 12622, Egypt
}

Correspondence should be addressed to Hazem A. Ghabbour; haghabbour@ksu.edu.sa

Received 1 October 2017; Revised 28 February 2018; Accepted 8 March 2018; Published 17 April 2018

Academic Editor: Teodorico C. Ramalho

Copyright (C) 2018 Mohamed A. Said et al. This is an open access article distributed under the Creative Commons Attribution License, which permits unrestricted use, distribution, and reproduction in any medium, provided the original work is properly cited.

Certain Biginelli pyrimidines with ester substitution in C5 were subjected to unexpected ring opening upon solvent-free reaction with hydrazine hydrate to give three products: pyrazole, arylidenehydrazines, and urea/thiourea, respectively. The nonisolable carbohydrazide intermediates are formed firstly followed by the intermolecular nucleophilic attack of terminal amino group of hydrazide function on $s p^{2} \mathrm{C} 6$ rather than the $s p^{3} \mathrm{C} 4$ to give the ring adduct which was produced as a final product.

\section{Introduction}

Pyrimidine derivatives Uracil and Thymine are an integral part of RNA and DNA, respectively. Compounds with pyrimidine scaffolds exhibit wide range of diverse pharmacological actions [1,2] and biological activities [3] such as anti-HIV agent Stavudine [4], antibiotic Fervennuline [5], antihypertensive drug Minoxidil [6], and antibacterial drug Sulfamethazine [7]. Pyrimidines of Biginelli type (3,4dihydropyrimidines, DHPMs) showed a broad spectrum of biological activities such as anticancer agent, Monastrol (Figure 1) $[8,9]$. The straight forward synthesis of DHPMs resulted in the discovery of many important agents such as calcium channel modulators, adrenergic receptor antagonists, and mitotic kinesin inhibitors, in addition to anticancer, anti-inflammatory, antimicrobial, and antioxidant activities [9-13].

Synthesis of DHPMs (4) is carried out through the reaction of urea/thiourea 1 , aldehyde 2 , and $\beta$-ketone 3
(Figure 1). This reaction was reported by Biginelli and Gazz in 1893 and was then catalyzed by acids [14]. DHPMs can be obtained by few other synthetic protocols $[9,15-17]$ and several improvements were made to obtain good reaction conditions and better yields [11, 18-27].

DHPMs could be developed with six diversity points $\left(\mathrm{R}_{1}\right.$, $\mathrm{X}, N_{3}, \mathrm{R}_{4}, \mathrm{R}_{5}$, and $\mathrm{R}_{6}$ ) [28] (Figure 1). When $\mathrm{R}_{1}=\mathrm{H}$, DHPMs 4 could be alkylated at $N_{1}$ [29] whereas the formylation or acylation of $N_{3}$ of 4 furnishes the $N_{3}$-formylated or $N_{3}$ acylated derivatives [30]. DHPMs $4(X=S)$ could be alkylated in the presence of base [30]. With respect to $\mathrm{R}_{4}$, the reaction works best with aromatic aldehydes [31]. On the other hand, when $R_{5}$ is an ester group, free carboxylic acids can be produced [32-34]. Finally, when $\mathrm{R}_{6}=\mathrm{Me}$, it can be subjected to bromination $[35,36]$. To the best of our knowledge, there are no reports concerned with the accessibility of C6 for the nucleophilic reaction by hydrazine hydrate. However, C5 esters reacted with hydrazine hydrate, in ethyl alcohol and in the presence of $\mathrm{H}_{2} \mathrm{SO}_{4}$, to give hydrazides $5[37,38]$ (Figure 1). 


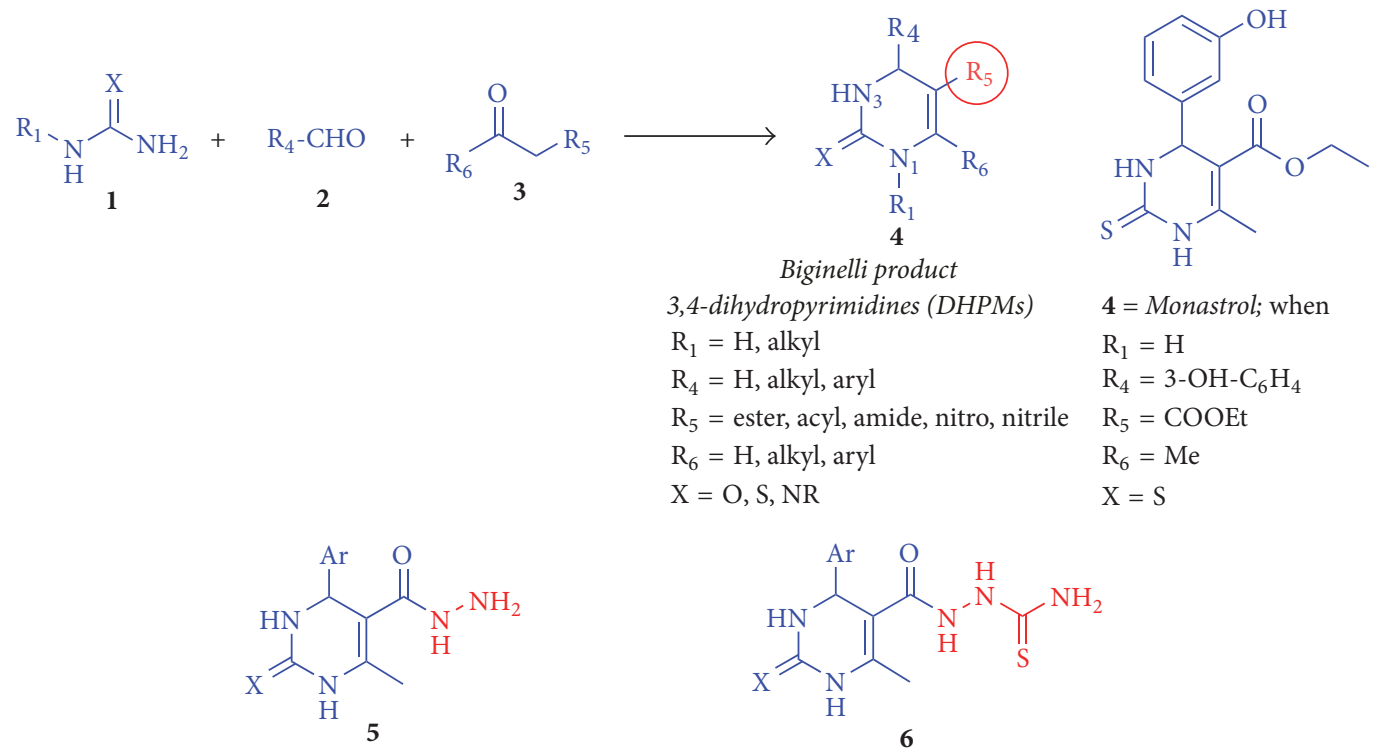

FIgURE 1: The structure of 3,4-dihydropyrimidinones (DHPMs) 4, anticancer agent Monastrol, hydrazide 5, and thiosemicarbazone 6.

The reaction of $\mathrm{C} 5$ esters with thiosemicarbazide, in acetone, to afford thiosemicarbazones 6 is reported (Figure 1) [39].

The latter data stimulate our interest to investigate the reactivity of $\mathrm{C} 5$ ester towards hydrazine hydrate under solvent-free conditions which produce three different ring cleavage products. This unexpected result leads us to perform further extensive survey in literature to discover the effect of hydrazine hydrate on pyrimidines other than DHPMs.

Interestingly, the reported findings revealed that the hydrazinolysis of pyrimidine-2(1H)-one (7a), 4-methylpyrimidin-2(1H)-one (7b), or 4,6-dimethylpyrimidin-2(1H)one $(7 \mathrm{c})$ resulted in the formation of $1 \mathrm{H}$-pyrazole (8a), 3methyl-1H-pyrazole (8b) and 3,5-dimethyl-1H-pyrazole (8c), respectively, in addition to urea (1a) in each case (Figure 2) [40]. Furthermore, we found that the reaction of pyrimidines $9 \mathbf{a}$ and $\mathbf{9 b}(\mathrm{R}=\mathrm{H}, \mathrm{R}=\mathrm{Me})$ with hydrazine hydrate gave pyrazoles 10a and 10b whereas the 2,4-dioxo-1,2,3,4tetrahydropyrimidine-5-carbaldehyde $9 \mathrm{c}(\mathrm{R}=-\mathrm{CHO})$ gave pyrazole derivative $10 \mathrm{c}$ (Figure 2) [41]. These facts showed the reactivity of $s p^{2}$ C6 of pyrimidines towards hydrazine hydrate and, subsequently, the ring opening of pyrimidine moiety.

Recently, we reported a unique behavior of hydrazine hydrate towards certain benzofurans to produce phenolicbased pyrazoles [42]. We also identified malonohydrazide as reaction product besides salicylaldehyde azine upon the reaction of ethyl 2-oxo- $2 \mathrm{H}$-chromene-3-carboxylate with hydrazine hydrate [43]. In the light of previous data and in continuation of our interest in the chemistry of hydrazine hydrate towards certain heterocycles [44-48], we aim herein to study the solvent-free reaction of hydrazine hydrate on C5 ester Biginelli pyrimidines $\mathbf{4 a - 4 h}$ (Figure 3).

\section{Experimental}

2.1. General. Melting points were measured with a Stuart melting point apparatus and were uncorrected. ${ }^{1} \mathrm{H}$ NMR
Spectra were recorded on a Varian Mercury NMR spectrometer. ${ }^{1} \mathrm{H}$ spectrum was run at $400 \mathrm{MHz}$ in deuterated dimethylsulfoxide $\left(\mathrm{DMSO}-d_{6}\right)$. Chemical shifts are expressed in values (ppm) using the solvent peak as internal standard. All coupling constant $(J)$ values are given in hertz. The abbreviations used are as follows: s: singlet; d: doublet; m: multiplet.

2.2. General Procedure for the Synthesis of Ethyl 6-Methyl-4(substituted)phenyl-2-(oxo/thioxo)-1,2,3,4-tetrahydropyrimidine-5-carboxylates $\mathbf{4 a - 4 h}$. To a solution of urea (1a)/thiourea (1b) $(0.050 \mathrm{~mol})$, different aromatic aldehydes $\mathbf{2 a - 2 d}$ $(0.075 \mathrm{~mol})$, and ethylacetoacetate $3 \mathbf{a}(0.075 \mathrm{~mol})$ in ethanol $(35 \mathrm{~mL})$, a catalytic amount of $\mathrm{CaCl}_{2}(0.020 \mathrm{~mol})$ was added. The reaction mixture was heated under reflux for $2 \mathrm{~h}$, and the progress of reaction was monitored by TLC. After reaction completion, the reaction mass was cooled and treated with crushed ice. Then the precipitated solid was filtered off, crystallized using methanol/water mixture, and then dried to give DHPMs $\mathbf{4 a - h}$.

2.3. The Reaction of DHPMs Esters $\mathbf{4 a}-\boldsymbol{h}$ with Hydrazine Hydrate in Ethanol. To a solution of DHPMs $4 \mathbf{a}-\mathbf{h}(0.01 \mathrm{~mol})$ in ethanol $(20 \mathrm{~mL})$, hydrazine hydrate $(0.03 \mathrm{~mol})$ was added. Then the reaction mixture was heated under reflux for $6 \mathrm{~h}$. The reaction progression was monitored using TLC, which indicated that no reaction occurred [37].

2.4. General Procedure for the Neat Reaction of DHPMs Esters $\mathbf{4 a}-\mathbf{4 h}$ with Hydrazine Hydrate. A mixture of DHPMs $\mathbf{4 a}-\mathbf{4 h}$ $(0.01 \mathrm{~mol})$ and excess hydrazine hydrate $(5 \mathrm{~mL})$ was heated under reflux for $6 \mathrm{~h}$. The reaction mixture was allowed to cool and poured on crushed ice. The obtained solid product 16a-16d was filtered, crystallized from ethanol, and finally dried. The evaporation of the filtrate gave solid residue which upon fractional crystallization from water gave the pyrazole 13 and urea (1a)/thiourea (1b), respectively. 

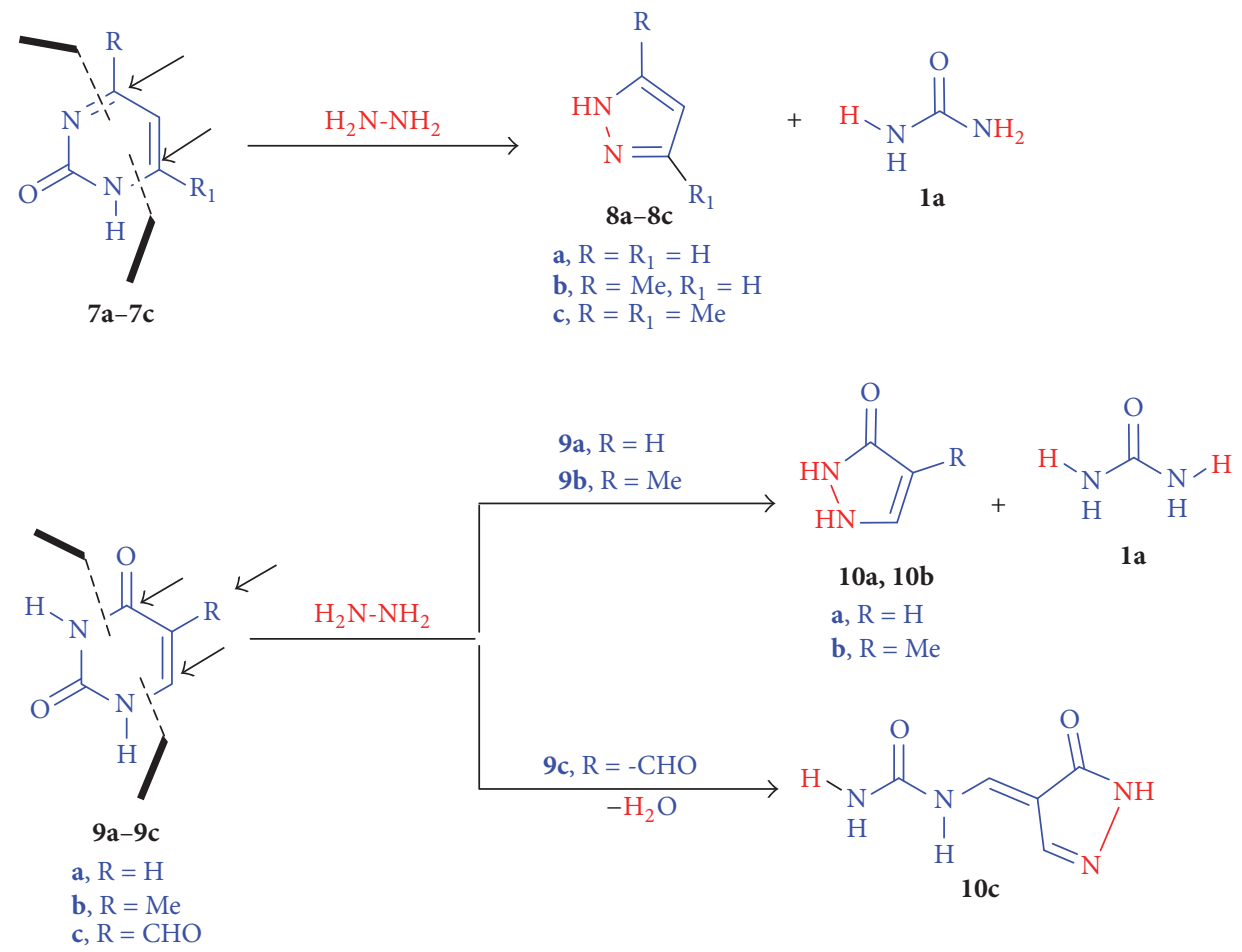

FIGURE 2: The reported reactions of hydrazine hydrate with pyrimidines $7 \mathbf{a}-7 \mathbf{c}$ and $9 \mathbf{a}-9 \mathbf{c}$.

2.4.1. 3-Methyl-1H-pyrazol-5-ol (13). Yield: $42-55 \%$ (for $4 \mathbf{4 a -}$ 4h); m.p. $221-223^{\circ} \mathrm{C}$ (Lit. [49] m.p. 220-222 ${ }^{\circ} \mathrm{C}$ ); ${ }^{1} \mathrm{H}-\mathrm{NMR}$ $\left(\mathrm{DMSO}-d_{6}\right) \delta$ (ppm): 2.47 (s, 3H, -CH3), $6.83(\mathrm{~s}, 1 \mathrm{H}, \mathrm{Ar}-\mathrm{H})$, 10.07 (s, 1H, OH), 12.10 (s, 1H, NH).

2.4.2. Benzylidenehydrazine (16a). Yield: $62 \%$ (for $\mathbf{4 a}$ ) and 67\% (for 4e); m.p. 89-91 ${ }^{\circ} \mathrm{C}$ (Lit. [50] m.p. 90-92 ${ }^{\circ} \mathrm{C}$ ); ${ }^{1} \mathrm{H}-\mathrm{NMR}$ (DMSO- $\left.d_{6}\right) \delta(\mathrm{ppm}): 5.37\left(\mathrm{~s}, 2 \mathrm{H}, \mathrm{NH}_{2}, \mathrm{D}_{2} \mathrm{O}\right.$-exchangeable), 7.38-7.41 (m, 3H, Ar-H), 7.64 (d, J=8.0 Hz, 2H, Ar-H,), 7.71 (s, $1 \mathrm{H}, \mathrm{CH}=\mathrm{N})$.

2.4.3. 4-Methylbenzylidenehydrazine (16b). Yield: 58\% (for 4b) and $69 \%$ (for 4f); m.p. 58-59 ${ }^{\circ} \mathrm{C}$ (Lit. [51] m.p. 55-56 ${ }^{\circ} \mathrm{C}$ ); ${ }^{1} \mathrm{H}-\mathrm{NMR}$ (DMSO- $\left.d_{6}\right) \delta(\mathrm{ppm}): 2.21\left(\mathrm{~s}, 3 \mathrm{H}, \mathrm{CH}_{3}\right), 5.31(\mathrm{~s}, 2 \mathrm{H}$, $\mathrm{NH}_{2}, \mathrm{D}_{2} \mathrm{O}$-exchangeable), $6.96(\mathrm{~d}, J=8.0 \mathrm{~Hz}, 2 \mathrm{H}, \mathrm{Ar}-\mathrm{H}), 7.56$ $(\mathrm{d}, J=8.4 \mathrm{~Hz}, 2 \mathrm{H}, \mathrm{Ar}-\mathrm{H}), 7.70(\mathrm{~s}, 1 \mathrm{H}, \mathrm{CH}=\mathrm{N})$.

2.4.4. 4-Methoxybenzylidenehydrazine (16c). Yield: 60\% (for 4c) and $66 \%$ (for $4 \mathrm{~g}$ ); m.p. $161-162^{\circ} \mathrm{C}$ (Lit. [52] m.p. $168^{\circ} \mathrm{C}$ ); ${ }^{1} \mathrm{H}-\mathrm{NMR}\left(\mathrm{DMSO}-d_{6}\right) \delta(\mathrm{ppm}): 3.82\left(\mathrm{~s}, 3 \mathrm{H}, \mathrm{OCH}_{3}\right), 5.36(\mathrm{~s}$, $2 \mathrm{H}, \mathrm{NH}_{2}, \mathrm{D}_{2} \mathrm{O}$-exchangeable), $6.92(\mathrm{~d}, J=8.4 \mathrm{~Hz}, 2 \mathrm{H}, \mathrm{Ar}-\mathrm{H})$, $7.54(\mathrm{~d}, J=8.4 \mathrm{~Hz}, 2 \mathrm{H}, \mathrm{Ar}-\mathrm{H}), 7.75(\mathrm{~s}, 1 \mathrm{H},-\mathrm{CH}=\mathrm{N})$.

2.4.5. 4-Chlorobenzylidenehydrazine (16d). Yield: 62\% (for 4d) and $70 \%$ (for 4 h); m.p. $59-61^{\circ} \mathrm{C}$ (Lit. [53] m.p. 57-58 ${ }^{\circ} \mathrm{C}$ ); ${ }^{1} \mathrm{H}-\mathrm{NMR}$ (DMSO- $\left.d_{6}\right) \delta(\mathrm{ppm}): 5.38\left(\mathrm{~s}, 2 \mathrm{H}, \mathrm{NH}_{2}, \mathrm{D}_{2} \mathrm{O}-\right.$ exchangeable), $7.31(\mathrm{~d}, J=8.4 \mathrm{~Hz}, 2 \mathrm{H}, \operatorname{Ar}-\mathrm{H}), 7.70(\mathrm{~d}, J=$ $8.4 \mathrm{~Hz}, 2 \mathrm{H}, \mathrm{Ar}-\mathrm{H}), 7.77(\mathrm{~s}, 1 \mathrm{H},-\mathrm{CH}=\mathrm{N})$.

\section{Results and Discussion}

In a typical experimental procedure a solution of urea $(\mathrm{R}=\mathrm{H}$, $\mathrm{X}=\mathrm{O}, \mathbf{1 a})$ /thiourea $(\mathrm{R}=\mathrm{H}, \mathrm{X}=\mathrm{S}, \mathbf{1 b})$, aldehydes $\mathbf{2 a}-\mathbf{2 d}\left(\mathrm{R}_{4}=\right.$ $\mathrm{Ph}, 4-\mathrm{MeC}_{6} \mathrm{H}_{4}, 4-\mathrm{MeO}-\mathrm{C}_{6} \mathrm{H}_{4}, 4-\mathrm{Cl}-\mathrm{C}_{6} \mathrm{H}_{4}$ ), and ethyl acetoacetate $\left(\mathrm{R}_{5}=\mathrm{COOEt}, \mathrm{R}_{6}=\mathrm{Me}, \mathbf{3 a}\right)$ in absolute ethanol was heated under reflux in the presence of catalytic amount of $\mathrm{CaCl}_{2}$ to give the required DHPM derivatives $4 \mathbf{a}-4 \mathbf{h}$. Then, we heated DHPM derivatives $\mathbf{4 a}-\mathbf{4 h}$ with hydrazine hydrate in ethanol under reflux $(6 \mathrm{~h})$ but we gave no reaction [54]. The reaction of DHPM derivatives $\mathbf{4 a}-\mathbf{4 h}$ with excess amount of hydrazine hydrate, in absence of ethanol, under reflux for $6 \mathrm{~h}$ showed the disappearance of Biginelli pyrimidines $4 \mathbf{a}-\mathbf{4 h}$ on TLC. The latter reaction gave three products, none of them being the expected hydrazide 11a-11h.

The analyses of the isolated products established their assigned structure as pyrazole 13, arylidenehydrazines 16a-16d, and urea/thiourea la and $1 \mathbf{b}$ (Figure 3).

The previous conclusions encouraged us to suppose a mechanism for ring opening of DHPMs by hydrazine hydrate (Figure 3). This reaction proceeds through the formation of nonisolable intermediate carbohydrazide $11 \mathbf{a}-11 \mathbf{h}$ at $\mathrm{C} 5 \mathrm{fol}-$ lowed by nucleophilic attack of $-\mathrm{NH}_{2}$ of hydrazide on $s p^{2} \mathrm{C} 6$ rather than the $s p^{3} \mathrm{C} 4$ to give the ring opening adducts 12a-12h which produce pyrazole $\mathbf{1 3}$ as final product in addition to arylidene of urea/thiourea $\mathbf{1 4 a}-\mathbf{1 4 h}$ as nonisolable intermediate. Additional hydrazinolysis of $\mathbf{1 4 a - 1 4 h}$ gave arylidenehydrazines $\mathbf{1 6} \mathbf{a}-\mathbf{1 6} \mathbf{d}$ and urea/thiourea $\mathbf{1 a}$ and $\mathbf{1 b}$ as end products. 

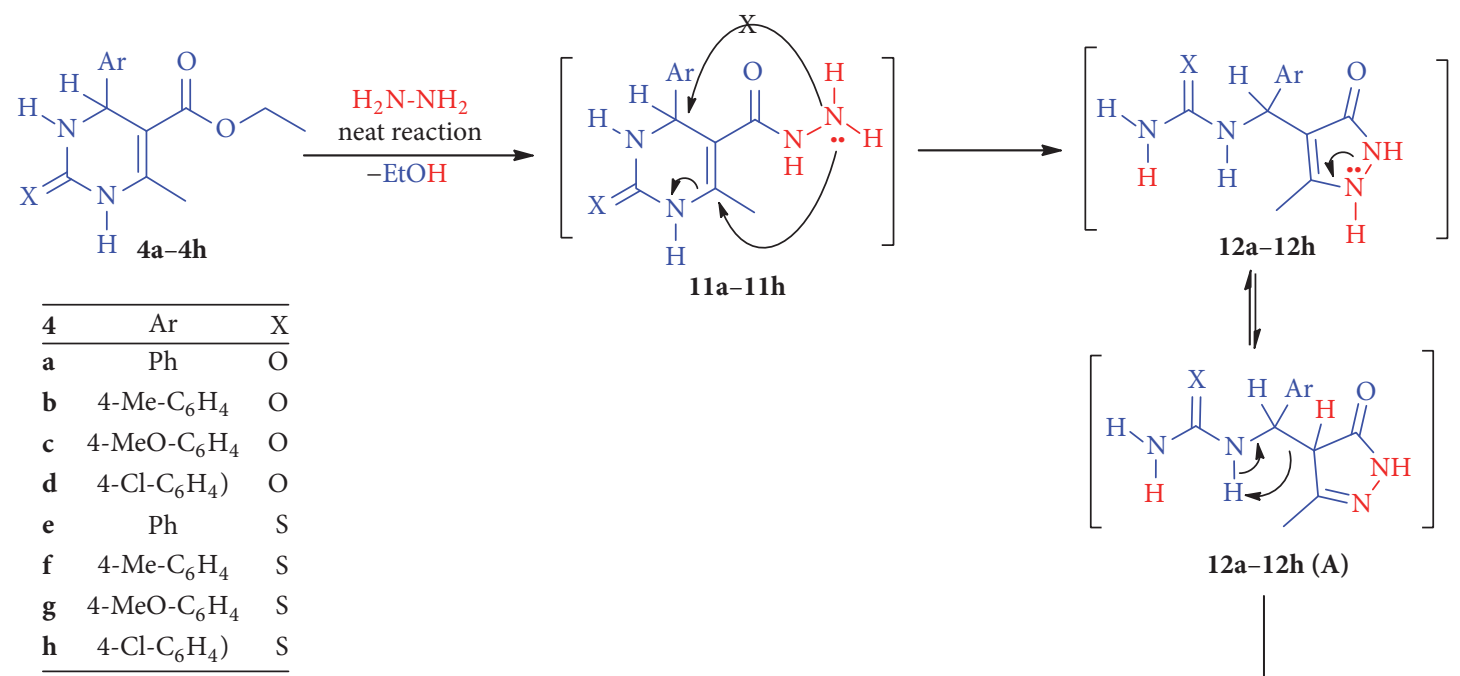

$12 \mathrm{a}-12 \mathrm{~h}(\mathrm{~A})$

- $\left.4-\mathrm{Cl}_{6} \mathrm{H}_{4}\right) \quad \mathrm{S}$

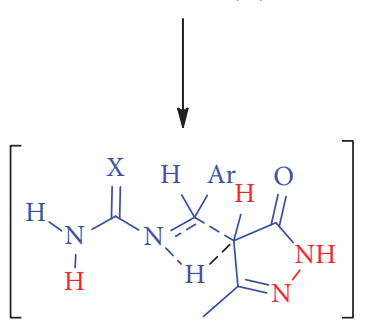

$12 \mathrm{a}-12 \mathrm{~h}(\mathrm{~B})$

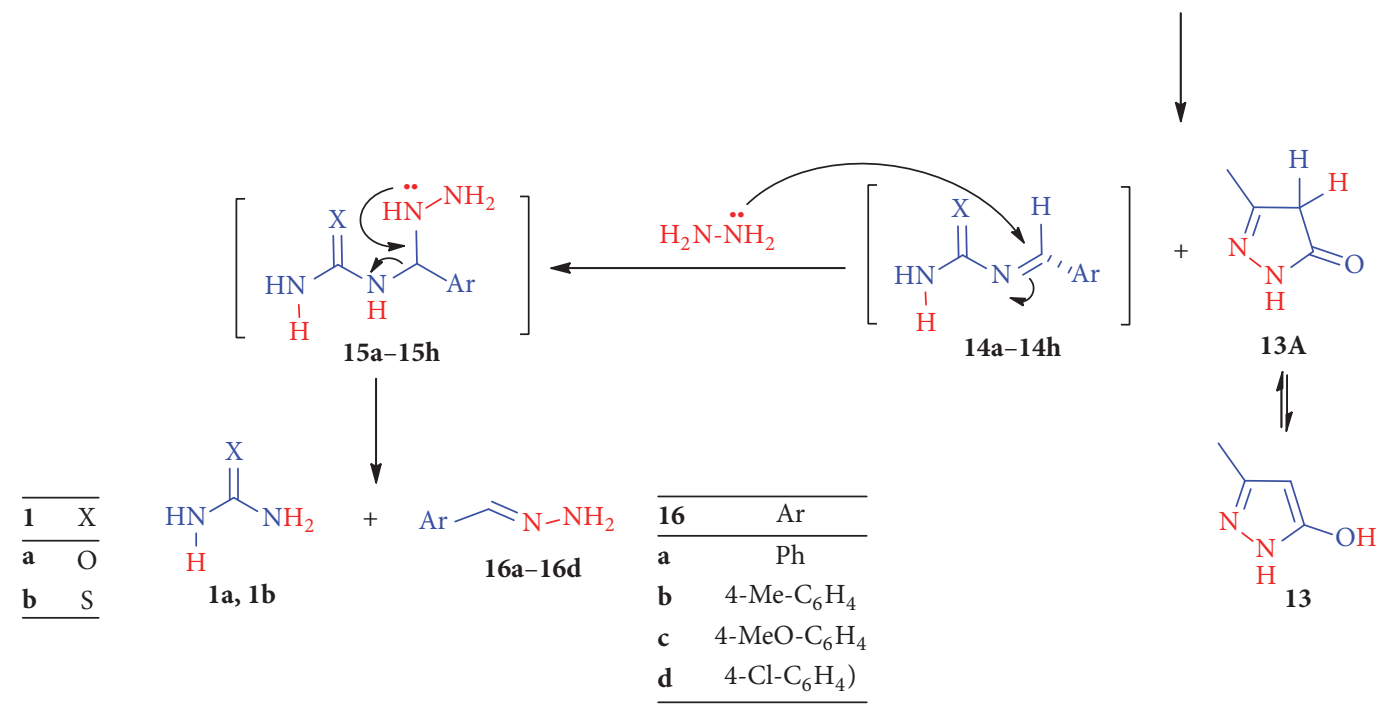

FIGURE 3: The proposed mechanism for the reaction of DHPM derivatives $\mathbf{4 a}-\mathbf{4 h}$ with hydrazine hydrate.

\section{Conclusion}

We studied the action of hydrazine hydrate as $N$-nucleophile on Biginelli pyrimidine esters $\mathbf{4 a}-\mathbf{4 h}$. They were subjected to unexpected ring cleavage to give pyrazole 13 , arylidenehydrazines 16a-16d, and urea/thiourea $1 \mathbf{a}$ and $\mathbf{1 b}$ where the reaction proceeded through $\mathrm{C} 5$ ester and C6.

\section{Conflicts of Interest}

The authors declare no conflicts of interest.

\section{Acknowledgments}

The authors would like to extend their sincere appreciation to the Deanship of Scientific Research at King Saud University for its funding of this research through the Research Group, Project no. RGP-1436-038.

\section{Supplementary Materials}

Graphical abstract figure shows the ring opening of certain Biginelli pyrimidines using hydrazine. (Supplementary Materials) 


\section{References}

[1] B. Ramesh and C. M. Bhalgat, "Novel dihydropyrimidines and its pyrazole derivatives: Synthesis and pharmacological screening," European Journal of Medicinal Chemistry, vol. 46, no. 5, pp. 1882-1891, 2011.

[2] J. Hashim, N. Arshad, I. Khan, S. Nisar, B. Ali, and M. Iqbal Choudhary, "Preparation of dihydrotetrazolo[1,5-a]pyrimidine derivatives from Biginelli 3,4-dihydropyrimidine-2-thiones," Tetrahedron, vol. 70, no. 45, pp. 8582-8587, 2014.

[3] S. Mohana Roopan and R. Sompalle, "Synthetic chemistry of pyrimidines and fused pyrimidines: A review," Synthetic Communications, vol. 46, no. 8, pp. 645-672, 2016.

[4] E. De Clercq, "Anti-HIV drugs: 25 compounds approved within 25 years after the discovery of HIV," International Journal of Antimicrobial Agents, vol. 33, no. 4, pp. 307-320, 2009.

[5] C. DeBoer, A. Dietz, J. Evans, and R. Michaels, Antibiotics Annual, vol. 7, p. 26, 1958.

[6] D. A. Sica, "Minoxidil: an underused vasodilator for resistant or severe hypertension.," Journal of clinical hypertension (Greenwich, Conn.), vol. 6, no. 5, pp. 283-287, 2004.

[7] B. Cancho Grande, M. S. García Falcón, M. Rodríguez Comesaña, and J. Simal Gándara, "Determination of sulfamethazine and trimethoprim in liquid feed premixes by HPLC and diode array detection, with an analysis of the uncertainty of the analytical results," Journal of Agricultural and Food Chemistry, vol. 49, no. 7, pp. 3145-3150, 2001.

[8] U. Soumyanarayanan, V. G. Bhat, S. S. Kar, and J. A. Mathew, "Monastrol mimic Biginelli dihydropyrimidinone derivatives: synthesis, cytotoxicity screening against HepG2 and HeLa cell lines and molecular modeling study," Organic and Medicinal Chemistry Letters, vol. 2, no. 1, p. 23, 2012.

[9] C. O. Kappe, "Recent advances in the Biginelli dihydropyrimidine synthesis. New tricks from an old dog," Accounts of Chemical Research, vol. 33, no. 12, pp. 879-888, 2000.

[10] F. S. Falsone and C. O. Kappe, "The Biginelli dihydropyrimidone synthesis using polyphosphate ester as a mild and efficient cyclocondensation/dehydration reagent," Arkivoc, vol. 2001, no. 2, pp. 122-134, 2001.

[11] M. O. M'hamed, A. G. Alshammari, and O. M. Lemine, "Green high-yielding one-pot approach to Biginelli reaction under catalyst-free and solvent-free ball milling conditions," Applied Sciences (Switzerland), vol. 6, no. 12, article no. 431, 2016.

[12] M. Barbero, S. Cadamuro, and S. Dughera, "A Brønsted acid catalysed enantioselective Biginelli reaction," Green Chemistry, vol. 19, no. 6, pp. 1529-1535, 2017.

[13] Â. de Fátima, T. C. Braga, L. D. S. Neto et al., "A mini-review on Biginelli adducts with notable pharmacological properties," Journal of Advanced Research, vol. 6, no. 3, pp. 363-373, 2015.

[14] P. Biginelli and P. Gazz, "Synthesis of 3, 4-dihydropyrimidin2 (1H)-ones," Gazzetta Chimica Italiana, vol. 23, pp. 360-416, 1893.

[15] B. O'reilly and K. Atwal, "Synthesis of substituted 1,2,3,4Tetrahydro-6-methyl-2-oxo-5-pyrimidinecarboxylic acid esters: The Biginelli condensation revisited," Heterocycles, vol. 26, no. 5, pp. 1185-1188, 1987.

[16] K. S. Atwal, B. C. O’Reilly, J. Z. Gougoutas, and M. F. Malley, "Synthesis of substituted 1,2,3,4-tetrahydro-6-methyl-2-thioxo5-pyrimidinecarboxylic acid esters," Heterocycles, vol. 26, no. 5, pp. 1189-1192, 1987.

[17] K. S. Atwal, G. C. Rovnyak, B. C. O'Reilly, and J. Schwartz, "Substituted 1,4-Dihydropyrimidines. 3. Synthesis of Selectively
Functionalized 2-Hetero-1,4-dihydropyrimidines," The Journal of Organic Chemistry, vol. 54, no. 25, pp. 5898-5907, 1989.

[18] D. Angeles-Beltrán, L. Lomas-Romero, V. H. Lara-Corona, E. González-Zamora, and G. Negrón-Silva, "Sulfated zirconia-catalyzed synthesis of 3,4-dihydropyrimidin-2(1H)-ones (DHPMs) under solventless conditions: Competitive multicomponent Biginelli vs. Hantzsch reactions," Molecules, vol. 11, no. 10, pp. 731-738, 2006.

[19] R. Srinivasa, V. Divya, J. Shubha, and J. Chem, "Onepot three-component biginelli-type reaction to synthesize 5carboxanilide-dihydropyrimidinones catalyzed by ionic liquids in aqueous media," Journal of ChemTech Research, vol. 4, pp. $1720-1727,2012$.

[20] H. G. O. Alvim, T. B. De Lima, H. C. B. De Oliveira et al., "Ionic liquid effect over the biginelli reaction under homogeneous and heterogeneous catalysis," ACS Catalysis, vol. 3, no. 7, pp. 1420$1430,2013$.

[21] H. Qu, X. Li, F. Mo, and X. Lin, "Efficient synthesis of dihydropyrimidinones via a three-component Biginelli-type reaction of urea, alkylaldehyde and arylaldehyde," Beilstein Journal of Organic Chemistry, vol. 9, pp. 2846-2851, 2013.

[22] D. Ding and C. G. Zhao, "Primary Amine Catalyzed Biginelli Reaction for the Enantioselective Synthesis of 3,4Dihydropyrimidin-2(1H)-ones," European Journal of Organic Chemistry, vol. 2010, no. 20, pp. 3802-3005, 2010.

[23] X.-H. Chen, X.-Y. Xu, H. Liu, L.-F. Cun, and L.-Z. Gong, "Highly enantioselective organocatalytic Biginelli reaction," Journal of the American Chemical Society, vol. 128, no. 46, pp. 14802-14803, 2006.

[24] Y. Wang, J. Yu, Z. Miao, and R. Chen, "Bifunctional primary amine-thiourea-TfOH (BPAT-TfOH) as a chiral phase-transfer catalyst: the asymmetric synthesis of dihydropyrimidines," Organic \& Biomolecular Chemistry, vol. 9, no. 8, pp. 3050-3054, 2011.

[25] H. Murata, H. Ishitani, and M. Iwamoto, Organic \& Biomolecular Chemistry, vol. 8, no. 5, pp. 1202-1211, 2010.

[26] B. C. Ranu, A. Hajra, and U. Jana, "Indium(III) chloride-catalyzed one-pot synthesis of dihydropyrimidinones by a threecomponent coupling of 1,3-dicarbonyl compounds, aldehydes, and urea: An improved procedure for the Biginelli reaction," The Journal of Organic Chemistry, vol. 65, no. 19, pp. 6270-6272, 2000.

[27] Y. Ma, C. Qian, L. Wang, and M. Yang, "Lanthanide triflate catalyzed biginelli reaction. One-pot synthesis of dihydropyrimidinones under solvent-free conditions," The Journal of Organic Chemistry, vol. 65, no. 12, pp. 3864-3868, 2000.

[28] M. J. Climent, A. Corma, and S. Iborra, "Homogeneous and heterogeneous catalysts for multicomponent reactions," RSC Advances, vol. 2, no. 1, pp. 16-58, 2012.

[29] T. George, R. Tahilramani, and D. Mehta, "Condensed heterocycles from 5-Ethoxycarbonyl-6-methyltetrahydropyrimidin2-ones," Synthesis, vol. 1975, no. 6, pp. 405-407, 1975.

[30] C. O. Kappe and P. Roschger, "Synthesis and reactions of "biginelli-compounds". Part I," Journal of Heterocyclic Chemistry, vol. 26, no. 1, pp. 55-64, 1989.

[31] C. O. Kappe and A. Stadler, "The Biginelli dihydropyrimidine synthesis," in Organic Reactions, 2004.

[32] G. Zigeuner, C. Knopp, and H. Blaschke, "Tetrahydro-6methyl- and- 6-phenyl-2-oxopyrimidin-5-carboxylic acids and derivatives," Monatshefte für Chemie, vol. 107, no. 3, pp. 587-603, 1976. 
[33] B. Schnell, W. Krenn, K. Faber, and C. O. Kappe, "Synthesis and reactions of Biginelli-compounds. Part 23. Chemoenzymatic syntheses of enantiomerically pure 4-aryl-3,4-dihydropyrimidin-2(1H)-ones," Journal of the Chemical Society, Perkin Transactions 1, no. 24, pp. 4382-4389, 2000.

[34] C. O. Kappe, G. Uray, P. Roschger, W. Lindner, C. Kratky, and W. Keller, "Synthesis and reactions of biginelli compounds -5 . Facile preparation and resolution of a stable 5-dihydropyrimidinecarboxylic acid.," Tetrahedron, vol. 48, no. 26, pp. 54735480, 1992.

[35] G. Zigeuner, H. Hamberger, H. Blaschke, and H. Sterk, "Über Heterocyclen, 12. Mitt.: Zur Bromierung der 2-Oxo-6methyltetrahydropynimidine," Monatshefte für Chemie, vol. 97, no. 5, pp. 1408-1421, 1966.

[36] C. O. Kappe, "Synthesis and reactions of biginelli compounds, 3. Unexpected formation of nitriles from reactions of 6-(dibromomethyl)-1,2,3,4-tetrahydro-2-oxo-5-pyrimidinecarboxylates with sodium azide," European Journal of Organic Chemistry, vol. 1990, no. 5, pp. 505-507, 1990.

[37] T. N. Akhaja and J. P. Raval, "1,3-dihydro-2H-indol-2-ones derivatives: design, Synthesis, in vitro antibacterial, antifungal and antitubercular study," European Journal of Medicinal Chemistry, vol. 46, no. 11, pp. 5573-5579, 2011.

[38] T. N. Akhaja and J. P. Raval, "Design, synthesis and in vitro evaluation of tetrahydropyrimidine-isatin hybrids as potential antitubercular and antimalarial agents," Chinese Chemical Letters, vol. 23, no. 7, pp. 785-788, 2012.

[39] B. Andrews, K. Komathi, and S. Mohan, "Synthesis and comparing the antibacterial activities of pyrimidine derivatives," Journal of Chemical Sciences, vol. 129, no. 3, pp. 335-341, 2017.

[40] D. Brown, The Chemistry of Heterocyclic Compounds, Fused Pyrimidines: Pteridines, vol. 24, John Wiley \& Sons, 2009.

[41] K.-Y. Zee-Cheng and C. C. Cheng, "Reactions of Hydrazine and Methylhydrazine with Uracil-5-Carboxaldehyde. An Unusual Pyrimidine into Pyrazole Conversion," The Journal of Organic Chemistry, vol. 33, no. 2, pp. 892-894, 1968.

[42] H. A. Abdel-Aziz, P. Ahmad, A. Kadi, K. A. Al-Rashood, H. A. Ghabbour, and H.-K. Fun, "Unexpected ring-opening of 3 -aroylbenzo[b]furans at room temperature: a new route for the construction of phenol-substituted pyrazoles," Tetrahedron Letters, vol. 54, no. 26, pp. 3424-3426, 2013.

[43] H. A. Abdel-Aziz, T. Elsaman, M. I. Attia, and A. M. Alanazi, "The reaction of ethyl 2-oxo-2H-chromene-3-carboxylate with hydrazine hydrate," Molecules, vol. 18, no. 2, pp. 2084-2095, 2013.

[44] S. M. Abou-Seri, W. M. Eldehna, M. M. Ali, and D. A. Abou El Ella, "1-Piperazinylphthalazines as potential VEGFR-2 inhibitors and anticancer agents: Synthesis and in vitro biological evaluation," European Journal of Medicinal Chemistry, vol. 107, pp. 165-179, 2016.

[45] W. M. Eldehna, S. M. Abou-Seri, A. M. El Kerdawy et al., "Increasing the binding affinity of VEGFR-2 inhibitors by extending their hydrophobic interaction with the active site: Design, synthesis and biological evaluation of 1-substituted-4(4-methoxybenzyl)phthalazine derivatives," European Journal of Medicinal Chemistry, vol. 113, pp. 50-62, 2016.

[46] M. I. Attia, W. M. Eldehna, S. A. Afifi, A. B. Keeton, G. A. Piazza, and H. A. Abdel-Aziz, "New hydrazonoindolin-2-ones: Synthesis, exploration of the possible anti-proliferative mechanism of action and encapsulation into PLGA microspheres," PLoS ONE, vol. 12, no. 7, Article ID e0181241, 2017.
[47] H. A. Abdel-Aziz, H. A. Ghabbour, W. M. Eldehna et al., "2((Benzimidazol-2-yl)thio)-1-arylethan-1-ones: Synthesis, crystal study and cancer stem cells CD133 targeting potential," European Journal of Medicinal Chemistry, vol. 104, pp. 1-10, 2015.

[48] W. M. Eldehna, H. Almahli, G. H. Al-Ansary et al., "Synthesis and in vitro anti-proliferative activity of some novel isatins conjugated with quinazoline/phthalazine hydrazines against triple-negative breast cancer MDA-MB-231 cells as apoptosisinducing agents," Journal of Enzyme Inhibition and Medicinal Chemistry, vol. 32, no. 1, pp. 600-613, 2017.

[49] D. Dallinger and C. O. Kappe, "Creating chemical diversity space by scaffold decoration of dihydropyrimidines," Pure and Applied Chemistry, vol. 77, no. 1, pp. 155-161, 2005.

[50] M. Bingul, O. Tan, C. R. Gardner et al., "Synthesis, characterization and anti-cancer activity of hydrazide derivatives incorporating a quinoline moiety," Molecules, vol. 21, no. 7, article no. 916, 2016.

[51] B. Y. Dekova, M. J. Evers, L. R. Christiaens, and M. R. Guillaume, "The Reactivity of Selenium Dioxide Towards Aromatic Aldehydes Hydrazones, Azines and Phenylhydrazones: Carbonyl Regeneration and a New One-Pot Oxidation of Aldehydes to Aromatic Acids," Bulletin des Sociétés Chimiques Belges, vol. 96, no. 3, pp. 219-224, 1987.

[52] R. A. Squitieri, G. P. Shearn-Nance, J. E. Hein, and J. T. Shaw, "Synthesis of esters by in situ formation and trapping of diazoalkanes," The Journal of Organic Chemistry, vol. 81, no. 13, pp. 5278-5284, 2016.

[53] G. Singh and H. Zimmer, "Synthesis and Reactions of Some Triphenylphosphazines. The Use of Long-Range P31-H1 Coupling for Structure Determination," The Journal of Organic Chemistry, vol. 30, no. 2, pp. 417-420, 1965.

[54] M. A. Nasseri, M. Salimi, and A. A. Esmaeili, "Cellulose sulfuric acid as a bio-supported and efficient solid acid catalyst for synthesis of pyrazoles in aqueous medium," RSC Advances, vol. 4, no. 105, pp. 61193-61199, 2014. 

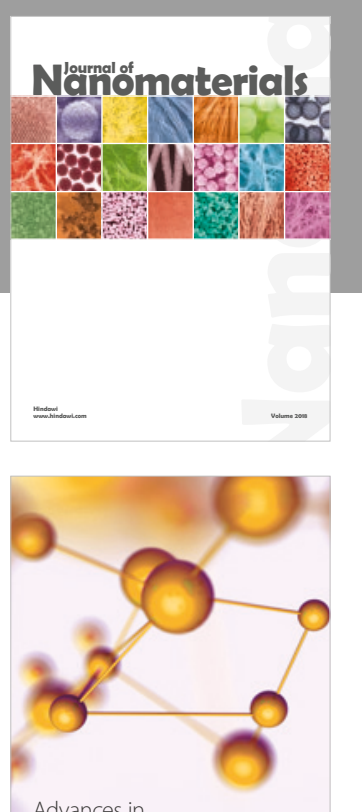

Physical Chemistry
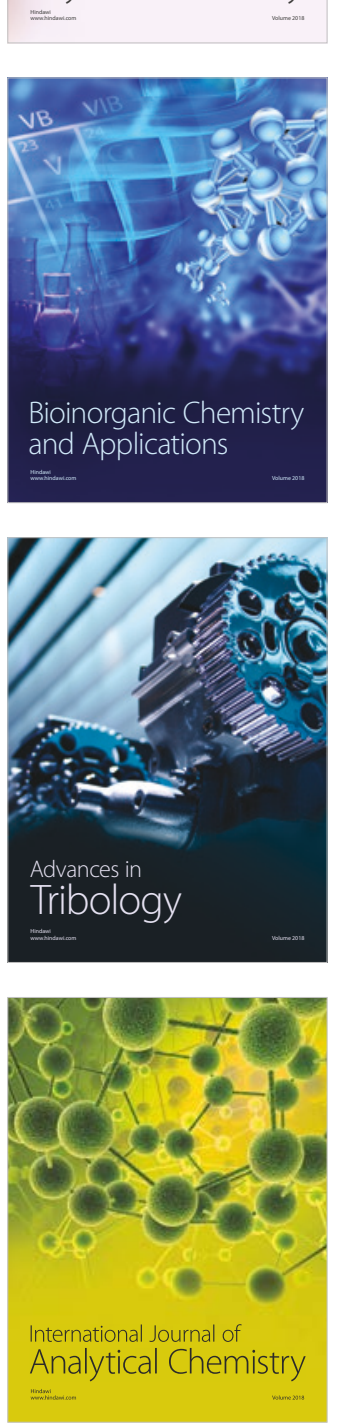

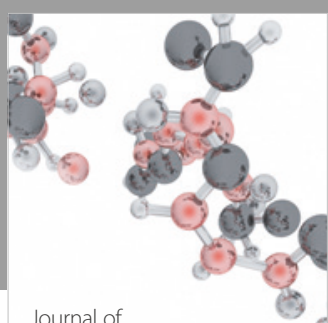

Analytical Methods

in Chemistry

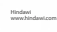

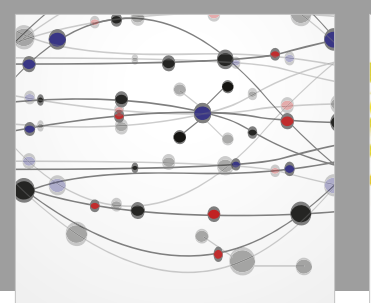

The Scientific World Journal

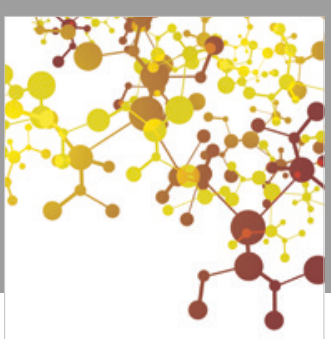

Journal of

Applied Chemistry
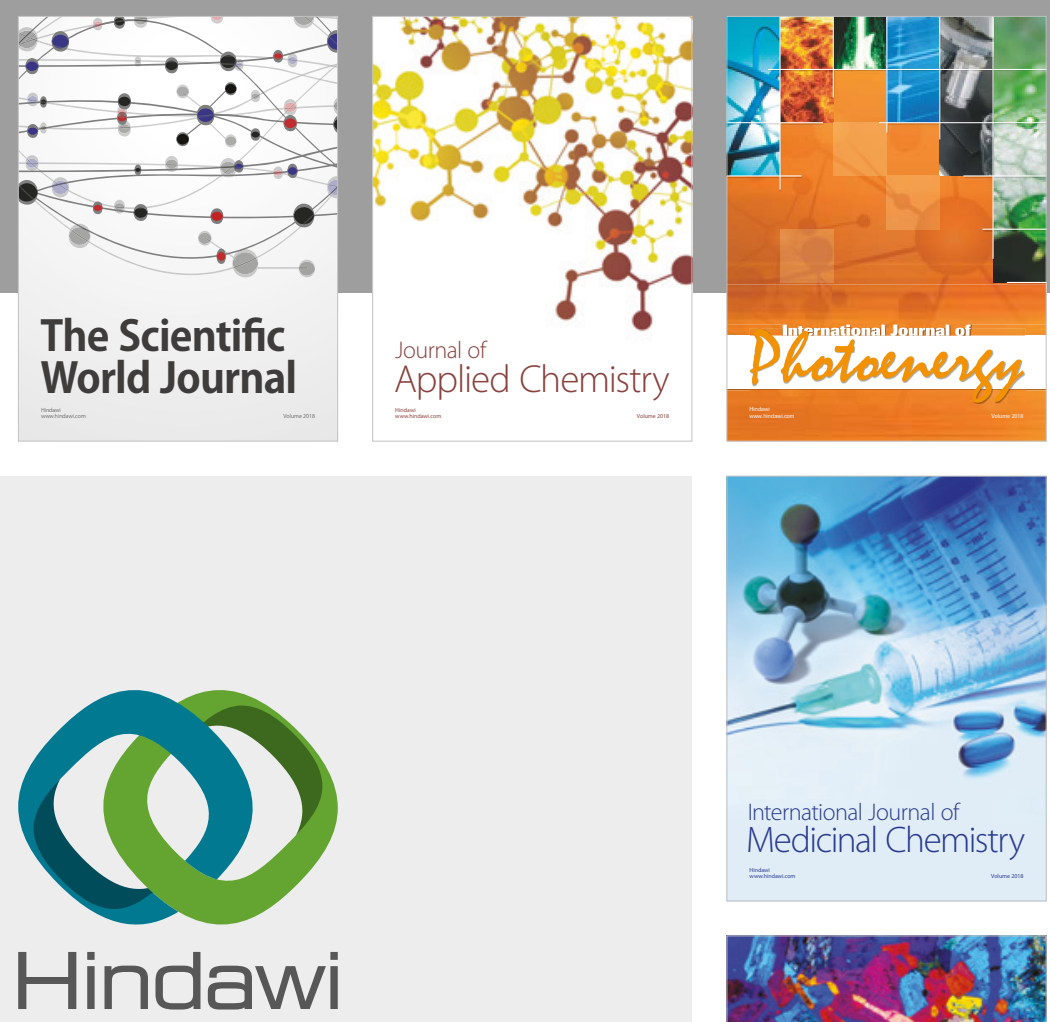

Submit your manuscripts at

www.hindawi.com
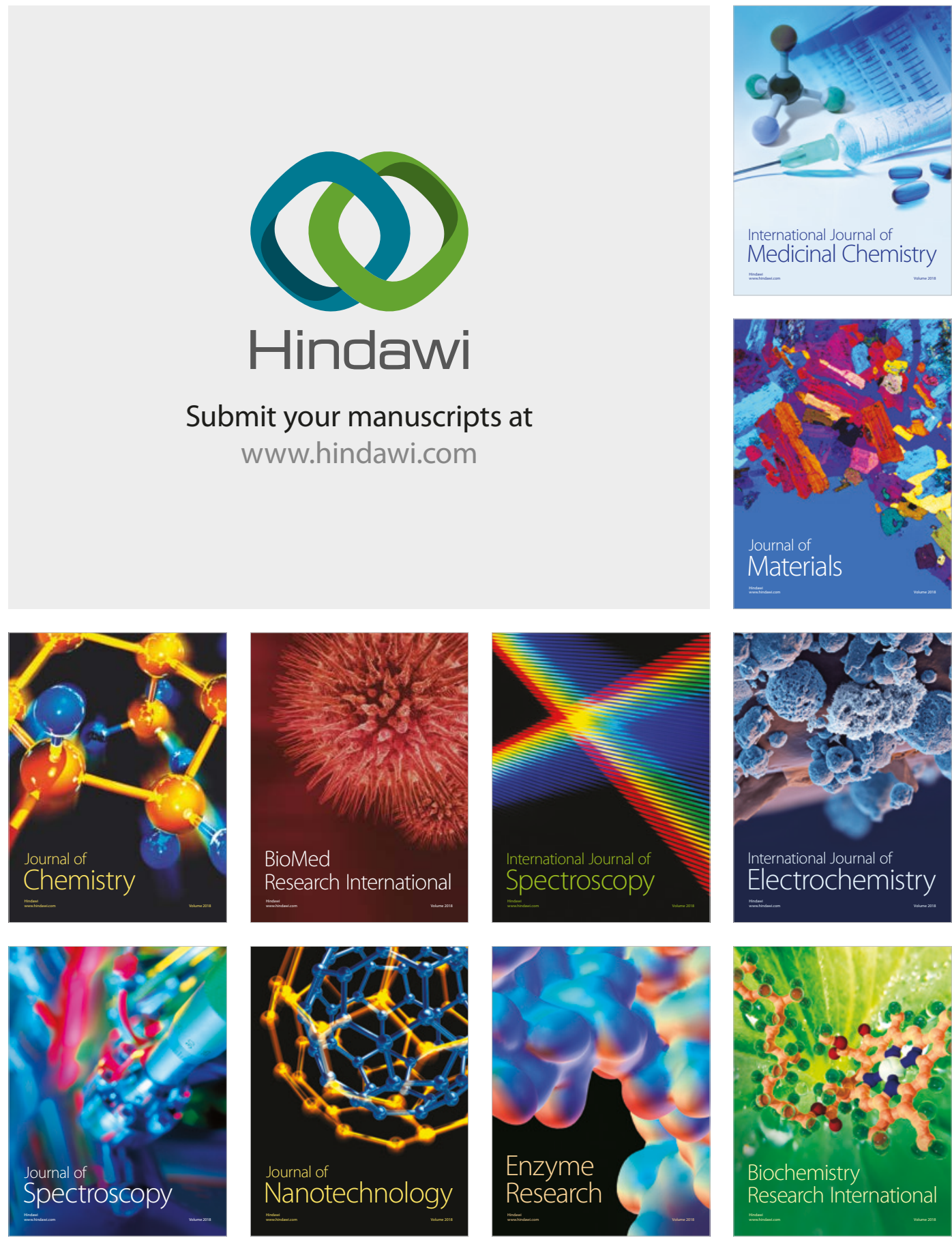
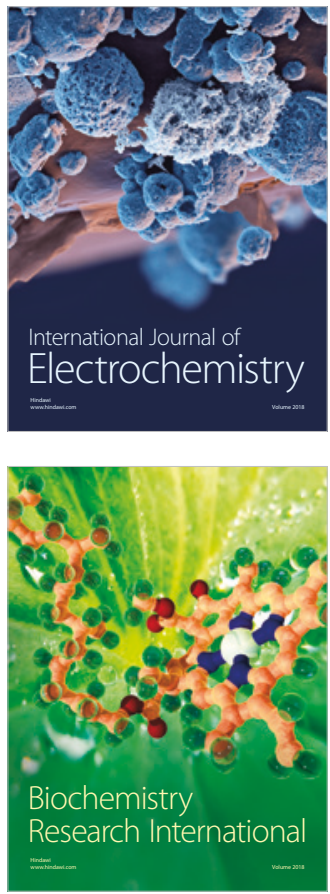